\title{
An appraisal of the mouse uterine weight assay for the bioassay of chorionic gonadotrophin in the macaque term placenta
}

\author{
B. M. Hobson \\ Reproductive Endocrinology Laboratory, Department of Obstetrics \& Gynaecology, \\ 37 Chalmers Street, Edinburgh EH3 9EW, U.K.
}

\begin{abstract}
Summary. The results obtained in this investigation have shown that the increase in uterine weight of 21-day-old mice, injected with monkey CG, was affected significantly by the number of injections made, the interval between injections and the time of autopsy after the first injection. Failure to take account of these factors may explain why some investigators, using the increase in mouse uterine weight as the index of response, do not find CG in macaque placentae after the 10 th week of pregnancy. The present investigation confirmed that extracts of term placentae from rhesus and stumptailed monkeys contained measurable amounts of CG whose biological activity could be neutralized by an anti-hCG serum.
\end{abstract}

\section{Introduction}

It has been reported that chorionic gonadotrophin $(\mathrm{CG})$ could be extracted from the placenta of the rhesus monkey (Macaca mulatta) throughout pregnancy (Hobson, 1972a, b; Hobson \& Wide, 1972, 1981). These observations were at variance with those of Hodgen, Niemann \& Tullner (1975) who were unable to detect $C G$ in rhesus monkey placentae after the 10th week of pregnancy. These differences are of interest, especially as both groups used a mouse uterine weight assay (Levin \& Tyndale, 1937) of apparently similar sensitivity. Fujiwara, Suzaki, Yamada \& Honjo (1980) used a similar assay to estimate the concentration of CG in placentae of cynomolgus monkeys $(M$. fascicularis). Only placentae obtained in the 4th and 5th week of gestation could be shown to contain gonadotrophin, which would seem to support the notion that the production of CG by macaques is limited to the first 10 weeks of pregnancy.

The availability of 2 term placentae from the stumptail macaque ( $M$. arctoides) and another term placenta from a rhesus monkey was an appropriate opportunity to supply more information about CG in macaque term placentae. However, the primary objective of the present study was to examine those factors that might influence the response of the immature mouse uterus to $\mathrm{CG}$ and to provide an explanation for the apparent absence of CG from macaque placentae after the 10th week of pregnancy.

\section{Materials and Methods}

Placentae. Two term placentae from laboratory-bred stump-tailed monkeys and 1 term placenta from a laboratory-bred rhesus monkey were obtained soon after delivery and extracted. The 
placentae, dissected free from umbilical cord and membranes, were homogenized in ice-cold acetone $(5 \mathrm{ml} / \mathrm{g})$ and ice-cold ether $(1 \mathrm{ml} / \mathrm{g})$. The homogenized tissue was kept at $+4^{\circ} \mathrm{C}$ overnight and collected by filtration on a Buchner funnel. This extraction method has been shown to remove steroids present in placental tissue of primates (Hobson, 1972a). Before assay, the dried acetoneether material was taken up in saline $(9 \mathrm{~g} \mathrm{NaCl} / 1)$, left overnight at $+4^{\circ} \mathrm{C}$, centrifuged, and the supernatant assayed.

hCG standard. The hCG laboratory standard was made in 1970 from 40 litres of pregnancy urine by the benzoic acid method of Katsman \& Doisy (1932). The resulting extract weighed $10 \cdot 2 \mathrm{~g}$ and had a biological activity equivalent to $100 \cdot 5 \pm 9 \cdot 2$ i.u. $\mathrm{hCG} / \mathrm{mg}$ 2nd International Standard for hCG. The laboratory standard was checked at yearly intervals against the International Standard and between 1970 and 1982 the potency range was $92-104 \mathrm{i} . \mathrm{u}$. hCG/mg with a mean $(n=13)$ relative potency of $99.9 \pm 3.6 \mathrm{i}$.u. hCG $/ \mathrm{mg}$. The laboratory standard has been used in this and all our previous investigations on the estimation of $\mathrm{CG}$ in mammalian placentae.

Animals. Immature female albino mice (Schofield), weighing 8-10 $\mathrm{g}$ and 21 days old on the first day of the assay or experiment, were used for the bioassay of CG. Animals were maintained under constant laboratory conditions of temperature and light, and food and water were always available.

Increasing age of mice is associated with increasing weight and pituitary activity until puberty which, in the Schofield strain, is reached at about 35 days with body weights between 25 and $30 \mathrm{~g}$. The effect of hCG upon the uterine weight of mice aged 21-35 days was investigated.

Response to oestrogen. The response of the uterus of immature mice to injected gonadotrophin is a secondary one stimulated by the production of ovarian steroids with a consequent increase in uterine weight. This uterotrophic effect can be achieved by injecting oestrogen and the amount required to produce a significant increase in uterine weight, over that of the controls, is a measure of the sensitivity of the target organ response. Mice, 10 per group, were injected with 5, 10, 20, 40, 80 or $160 \mathrm{ng}$ oestradiol $-17 \beta$ in arachis oil per mouse. The increase in uterine weight was compared with the response of mice injected with $0 \cdot 125,0.25$ and 0.5 i.u. hCG.

Bioassay. The gonadotrophic activity of placental extracts and hCG standards was assayed using the increase in uterine weight of immature female mice. The method was essentially that of Levin \& Tyndale (1937) in which mice were injected subcutaneously (s.c.) with one third of the total dose on 3 consecutive days and killed $72 \mathrm{~h}$ after the first injection. Uteri, dissected free from mesentery, fat, ovaries and oviducts, were cut at the uterocervical junction. Intrauterine fluid was expressed between filter paper before the uterus was weighed to the nearest $0 \cdot 1 \mathrm{mg}$ on a torsion balance.

Five or 10 mice were used at each of 2 or 3 dose levels, a log dose interval of 0.301 of the unknown and hCG standard preparations being assayed simultaneously. Estimates of relative potency of the placental extracts were expressed per $\mathrm{g}$ wet weight as International Unit equivalents of the Second International Standard for hCG (i.u. hCG). The smallest amount of hCG which produced a significant $(P<0.01)$ response in the bioassay, compared with that in saline-injected controls, was 0.625 i.u.

For comparison the response of mice to the hCG standard preparation was measured by the above method and simultaneously by the method of Fujiwara et al. (1980), in which mice were injected s.c. twice daily for 2 days and killed $96 \mathrm{~h}$ after the first injection.

The effects of hCG upon ovarian weight, the opening of the vagina, the presence of intrauterine fluid (hydrometra) and of haemorrhagic follicles in the mice used in the bioassays were recorded. These responses were not used in the calculations of relative potency of the monkey placental extracts and were of comparative interest only.

The response parameter was the logarithm of the mouse uterine weight. The results and tests of validity of the assays in this investigation were calculated according to Gaddum (1953).

Antiserum. The antiserum was a rabbit anti-hCG preparation raised against 'Gonadex' an hCG preparation (Leo, Sweden) having a biological activity of $5000 \mathrm{i} . \mathrm{u} . / \mathrm{mg}$. This antiserum was, by radioimmunoassay (Wide, 1969), shown to cross-react strongly with human luteinizing hormone 
(LH), have a very weak cross-reaction with human follicle-stimulating hormone (FSH) and not to cross-react with thyroid stimulating hormone.

Neutralization of gonadotrophic activity. Anti-hCG serum was used to see whether it would neutralize the gonadotrophic activity of the macaque placental extracts. These and the hCG standard were assayed with and without the addition of antiserum. The effect of this antiserum upon the biological activity of The Second International Reference Preparation of Human Menopausal Gonadotrophins, urinary, for Bioassay (IRP) was also tested. This preparation has an assigned potency of 40 i.u. FSH and 40 i.u. LH activity per ampoule (WHO, ECBS, 1964). The total amount of antiserum used was $15 \mu \mathrm{l}$ per total dose per mouse.

\section{Results}

Effect of age and body weight upon response

Groups of mice aged 21,24, 28 and 35 days were injected with saline or hCG. A linear response, between dose and uterine weight, was obtained when 21- and 24-day-old mice were injected with $0 \cdot 125,0.25$ and 0.5 i.u. hCG. However, the uterotrophic effect of hCG was depressed when $28-$ and 35 -day-old mice were injected with 0.25 i.u. hCG or more. The relationship between age and body weight and the effect of these upon the uterine weight of mice injected with saline or $0 \cdot 125 \mathrm{i}$.u. hCG is shown in Table 1. Age and body weight were positively correlated, $r=0.99$, and the correlations between age and uterine weight of the saline control group and the hCG group were $r=0.98$ and $r$ $=0.99$ respectively. The correlations between body weight and uterine weight of the saline- and hCG-injected groups were $r=0.97$ and $r=0.99$ respectively.

Table 1. Effect of age and body weight upon mouse uterine weight (mean \pm s.e.m.)

\begin{tabular}{lcccc}
\hline Treatment & $\begin{array}{c}\text { Age } \\
\text { (days) }\end{array}$ & $\begin{array}{c}\text { No. of } \\
\text { mice }\end{array}$ & $\begin{array}{c}\text { Body weight } \\
\text { (g) }\end{array}$ & $\begin{array}{c}\text { Uterine weight } \\
\text { (mg) }\end{array}$ \\
\hline Saline & 21 & 40 & $10 \cdot 6 \pm 0 \cdot 13$ & $6 \cdot 9 \pm 0 \cdot 17$ \\
& 24 & 20 & $14 \cdot 5 \pm 0 \cdot 47$ & $10 \cdot 4 \pm 0.36$ \\
& 28 & 15 & $18 \cdot 1 \pm 0 \cdot 28$ & $17 \cdot 7 \pm 0.62$ \\
& 35 & 10 & $25 \cdot 6 \pm 0 \cdot 85$ & $28.9 \pm 2 \cdot 18$ \\
hCG & 21 & 40 & $10 \cdot 2 \pm 0 \cdot 60$ & $11 \cdot 8 \pm 0.13$ \\
$(0 \cdot 125$ i.u.) & 24 & 20 & $14 \cdot 2 \pm 0 \cdot 34$ & $25 \cdot 9 \pm 2.48$ \\
& 28 & 20 & $18 \cdot 6 \pm 0.16$ & $53 \cdot 3 \pm 1.99$ \\
& 35 & 10 & $25 \cdot 7 \pm 0.92$ & $86 \cdot 4 \pm 7.85$ \\
\hline
\end{tabular}

Response to oestrogen

Table 2 shows the mean ( \pm s.e.) uterine weight of mice injected with oestradiol-17 $\beta$ and of mice injected with hCG. The dose-response relationship was identical over the linear portion of the log dose- $\log$ response line. The regression coefficient of $\log$ dose to $\log$ response was $r=0.99$ for both

Table 2. Response of mouse uterus to oestradiol-17 $\beta$ and hCG

\begin{tabular}{lccc}
\hline Hormone & Dose & $\begin{array}{c}\text { Mean } \pm \text { s.e.m. uterine } \\
\text { wt }(\mathrm{mg})^{*}\end{array}$ & $\begin{array}{c}\text { Slope value } \\
(\mathrm{b})\end{array}$ \\
\hline Oestradiol-17ß & $5 \mu \mathrm{g}$ & $12.8 \pm 0.36$ & \\
& $10 \mu \mathrm{g}$ & $26.9 \pm 0.99$ & 1.049 \\
& $20 \mu \mathrm{g}$ & $55.1 \pm 2.76$ & \\
hCG & 0.125 i.u. & $11.9 \pm 0.18$ & \multirow{2}{*}{1.046} \\
& 0.25 i.u. & $24.7 \pm 1.10$ & \\
\hline
\end{tabular}

* 15 mice per dose level. 
preparations and the slope value for oestradiol and hCG was $b=1.049$ and $b=1.046$ respectively. There was no significant increase in mean uterine weight with doses greater than $20 \mathrm{ng}$ oestradiol; higher doses tended to produce lower responses, as had been found when excessive amounts of hCG or rhesus monkey term placental extracts were injected (Text-fig. 1).

\section{Effect of dose upon response}

In the mouse uterine weight assay the doses of hCG standard usually employed were $0 \cdot 125,0 \cdot 25$ and 0.5 i.u. The mean \pm s.e.m. uterine weight of the saline injected controls was $6.9 \pm 0.09 \mathrm{mg}$. The smallest amount of hCG which produced a significant $(P<0.01)$ response over the control weight was 0.0625 i.u. There was a linear dose-response relationship between mean uterine weight and doses of the hCG standard up to $1.0 \mathrm{i}$.u. and of a rhesus monkey placental extract up to $50 \mathrm{mg}$. There was no significant increase in mean uterine weight with doses greater than these; higher doses usually suppressed the mean value and, as the s.e.m. values show, the response of individual mice to the same dose became erratic. Furthermore, the mean uterine weight produced by $50 \mathrm{mg}$ and $800 \mathrm{mg}$ of rhesus monkey placental extract $94 \mathrm{P}$ was the same. This emphasized the need to use more than one dose level of the unknown preparation to avoid underestimation of the biological activity (Text-fig. 1).
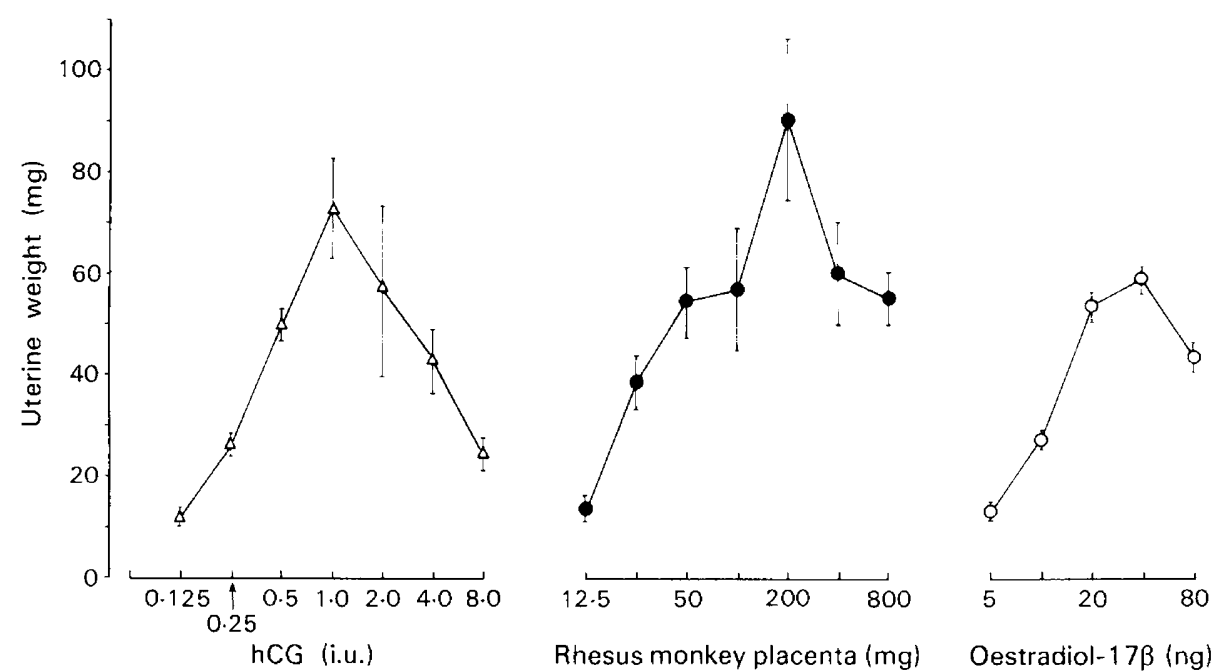

Text-fig. 1. The mean \pm s.e.m. response of the mouse uterus to increasing doses of the hCG standard, an extract of rhesus monkey term placenta, and oestradiol-17 $\beta$.

\section{Effect of dose schedule and autopsy time upon response}

Schofield mice aged 21 days achieved maximum uterine weights when injected with 1 i.u. hCG; larger amounts of gonadotrophin produced decreased responses (Text-fig. 1). Because of this it was not possible to make a dose-for-dose comparison between our bioassay and that used by Fujiwara et al. (1980), in which 1, 2 and 4 i.u. hCG were injected per mouse.

The increase in uterine weight and other indices of response to hCG are shown in Table 3. In mice killed $72 \mathrm{~h}$ after the first injection, compared with those killed at $96 \mathrm{~h}$, the mean uterine weight at all dose levels was significantly greater $(P<0.0001)$. Intrauterine fluid (hydrometra) was present in 24/30 mice killed at $72 \mathrm{~h}$ compared with $0 / 30$ for mice killed at $96 \mathrm{~h}(P<0.001)$. Irrespective of the time at which mice were killed, haemorrhagic follicles were not found in their ovaries and the number of mice with the vagina open was not significantly $(P>0.5)$ different at any of the 3 dose levels. 
The increase in mouse uterine weight to lower doses of hCG was examined using the dose schedule of Fujiwara et al. (1980) and by varying the time at which mice were killed. For comparison the assay method used routinely was done in parallel. The results obtained in this and the previous experiment showed that at all dose levels there was a significant $(P<0.01)$ reduction in uterine weight of mice killed $96 \mathrm{~h}$ (Group $\mathrm{C}$ ) after the first injection compared with the response of mice killed at 48 or $72 \mathrm{~h}$ (Groups A, B and D). Moreover, there was a significant $(P<0 \cdot 01)$ increase in uterine weight of mice autopsied at $72 \mathrm{~h}$ when hCG was injected once a day for 3 days (Group D) instead of twice a day for 2 days (Group B) (Table 4).

Table 3. Response of mouse uterus, ovary, vaginal opening, haemorrhagic follicles and hydrometra to hCG

\begin{tabular}{ccccccc}
\hline \multirow{2}{*}{$\begin{array}{c}\text { Total dose per } \\
\text { mouse } \\
\text { (i.u. hCG)* }\end{array}$} & $\begin{array}{c}\text { Uterine wt } \\
(\mathrm{mg})\end{array}$ & $\begin{array}{c}\text { Ovarian wt } \\
(\mathrm{mg})\end{array}$ & & $\begin{array}{c}\text { Vagina } \\
\text { open }\end{array}$ & $\begin{array}{c}\text { Haemorrhagic } \\
\text { follicles }\end{array}$ & Hydrometra \\
\cline { 2 - 3 } & $42.1 \pm 0.02$ & $3.9 \pm 0.09$ & $7 / 10$ & $0 / 10$ & $8 / 10$ \\
$0.4 \dagger$ & $60.7 \pm 6.55$ & $4.1 \pm 0.12$ & $7 / 10$ & $0 / 10$ & $9 / 10$ \\
$0.8 \dagger$ & $60.3 \pm 7.34$ & $4.2 \pm 0.17$ & $8 / 10$ & $0 / 10$ & $7 / 10$ \\
$1.6 \dagger$ & $8.7 \pm 0.32$ & $3.8 \pm 0.06$ & $4 / 10$ & $0 / 10$ & $0 / 10$ \\
$0.4 \ddagger$ & $12.2 \pm 0.60$ & $3.8 \pm 0.06$ & $8 / 10$ & $0 / 10$ & $0 / 10$ \\
$0.8 \ddagger$ & $18.3 \pm 1.83$ & $4.0 \pm 0.09$ & $9 / 10$ & $0 / 10$ & $0 / 10$ \\
$1.6 \ddagger$ & & & & & \\
\hline
\end{tabular}

* 10 mice per dose.

$\dagger$ Injected once per day for 3 days and autopsied $72 \mathrm{~h}$ after 1 st injection.

$\ddagger$ Injected twice (a.m. and p.m.) per day for 2 days and autopsied $96 \mathrm{~h}$ after 1 st injection.

Table 4. Effect of autopsy time and dose schedule upon mouse uterine weight to injected hCG standard

\begin{tabular}{|c|c|c|c|c|}
\hline & Group $A^{*}$ & Group B* & Group $C^{*}$ & Group $\mathrm{D} \dagger$ \\
\hline $\begin{array}{l}\text { Injections at (h) } \\
\text { Autopsy at (h) }\end{array}$ & $\begin{array}{c}0,24 \\
48\end{array}$ & $\begin{array}{c}0,24 \\
72\end{array}$ & $\begin{array}{c}0,24 \\
96\end{array}$ & $\begin{array}{c}0,24,48 \\
72\end{array}$ \\
\hline i.u. hCG per mouse & \multicolumn{4}{|c|}{ Mean \pm s.e.m. uterine weight $(N=5)$} \\
\hline $0 \cdot 125$ & $10 \cdot 1 \pm 0.56$ & $8 \cdot \overline{7} \pm 0 \cdot 20$ & $7 \cdot 4 \pm 0 \cdot 33$ & $11 \cdot 8 \pm 0 \cdot 29$ \\
\hline $0 \cdot 25$ & $11.0 \pm 0.47$ & $11 \cdot 1 \pm 0.62$ & $8.8 \pm 0.43$ & $22.5 \pm 1.07$ \\
\hline $0 \cdot 5$ & $23 \cdot 7 \pm 2 \cdot 32$ & $21 \cdot 7 \pm 0.85$ & $9 \cdot 9 \pm 0.49$ & $49 \cdot 2 \pm 2 \cdot 01$ \\
\hline
\end{tabular}

* Two, a.m. and p.m., s.c. injections per day.

$\dagger 1$ s.c. injection per day.

\section{$C G$ activity in monkey placental extracts}

In the present investigation and those previously reported the $\mathrm{CG}$ concentration in term placentae from 9 rhesus and 2 stump tailed monkeys was 0.79-29.7 i.u. hCG equivalents per $g$ wet weight. The geometric mean concentration was $7.07 \pm 0.96 \mathrm{i} . \mathrm{u} . / \mathrm{g}$. No significant departure from parallelism or linearity between $\log$ dose and $\log$ response of the placental extracts and the hCG standard was observed. An index of precision $\lambda$ was calculated for each assay (Gaddum, 1931): the median value for $\lambda$ was $0 \cdot 099$ (range $0 \cdot 011-0 \cdot 178$ ). These $\lambda$ values are comparable to those obtained with other bioassay methods for hCG (Diczfalusy, 1954).

\section{Neutralization of biological activity}

The biological activity of the hCG standard and the macaque term placental extracts was suppressed by an anti-hCG serum. The mean uterine weights of mice injected with hCG only were significantly $(P<0.003)$ greater than those of the saline controls and those of the mice injected 
with hCG and antiserum $(P<0 \cdot 001)$. The mean uterine weights of mice injected with hCG plus antiserum were not significantly $(P>0 \cdot 1)$ heavier than those of the saline controls (Table 5).

Similarly, the biological activity of the urinary LH material (IRP) was neutralized by the antihCG serum.

Table 5. Neutralization with an anti-hCG serum of the biological activity of macaque term placental extracts, the hCG standard and urinary LH preparation (IRP)

\begin{tabular}{|c|c|c|c|c|}
\hline \multirow[b]{2}{*}{ Species } & \multirow[b]{2}{*}{ Material } & \multirow[b]{2}{*}{ Dose } & \multicolumn{2}{|c|}{ Mean \pm s.e.m. uterine wt $(\mathrm{mg})^{*}$} \\
\hline & & & With antiserum & Without antiserum \\
\hline M. mulatta & Term placenta & $\begin{array}{l}10 \mathrm{mg} \\
20 \mathrm{mg} \\
40 \mathrm{mg}\end{array}$ & $\begin{array}{l}7.2 \pm 0.33 \\
7.2 \pm 0.25 \\
7.9 \pm 0.40\end{array}$ & $\begin{array}{l}11 \cdot 3 \pm 0.72 \\
22 \cdot 1 \pm 1.52 \\
38.3 \pm 1.83\end{array}$ \\
\hline$M$. arctoides & Term placenta & $\begin{array}{l}20 \mathrm{mg} \\
40 \mathrm{mg}\end{array}$ & $\begin{array}{l}7.0 \pm 0.09 \\
7.5 \pm 0.35\end{array}$ & $\begin{array}{l}11.7 \pm 0.53 \\
22.5 \pm 1.25\end{array}$ \\
\hline \multirow[t]{4}{*}{$M$. arctoides } & Term placenta & $\begin{array}{l}40 \mathrm{mg} \\
80 \mathrm{mg}\end{array}$ & $\begin{array}{l}6.9 \pm 0.07 \\
7.6 \pm 0.34\end{array}$ & $\begin{array}{l}11 \cdot 6 \pm 0.57 \\
21 \cdot 5 \pm 1 \cdot 36\end{array}$ \\
\hline & hCG standard & $\begin{array}{l}0.125 \text { i.u. } \\
0.25 \text { i.u. } \\
0.50 \text { i.u. }\end{array}$ & $\begin{array}{l}7.3 \pm 0.85 \\
6.9 \pm 0.20 \\
6.9 \pm 0.35\end{array}$ & $\begin{array}{l}11.2 \pm 0.54 \\
22.9 \pm 1.92 \\
41.8 \pm 3.26\end{array}$ \\
\hline & IRP & $\begin{array}{l}0.2 \text { i.u. } \\
0.4 \text { i.u. }\end{array}$ & $\begin{array}{l}6 \cdot 6 \pm 0 \cdot 18 \\
7 \cdot 2 \pm 0.39\end{array}$ & $\begin{array}{l}11 \cdot 1 \pm 0.59 \\
24.7 \pm 1.59\end{array}$ \\
\hline & Saline control & $3.0 \mathrm{ml}$ & & $6.9 \pm 0.35$ \\
\hline
\end{tabular}

${ }^{*} \mathrm{~N}=5$ except for saline control for which $\mathrm{N}=10$.

\section{Discussion}

The increase in ovarian and uterine weight of mice injected with hCG has been shown to be strain dependent (Hummel, 1942; Brown, Cunningham \& Finegan, 1959; Chai, 1960). It is advisable therefore to determine by experiment the suitability of a particular strain for the assay of hCG. The inability of Fujiwara et al. (1980) to detect CG in placentae of cynomolgus monkeys after the 5th week of gestation could be due to the insensitivity of the assay mice and/or the injection technique used. Doubling the dose of hCG produced a small increase in mouse uterine weight in their assay and the slope value $(b)$ of the regression line was 0.299 and significantly different $(P<0.001)$ from 1. The slope of this line was flat compared with the response of Schofield mice for which $b$ was 0.964 and $\mathbf{0 . 9 2 3}$ for the hCG standard and the rhesus monkey placental extract respectively (Text-fig. 1). Burn, Finney \& Goodwin (1950) pointed out that when using bioassay methods it was "unwise to be satisfied with results unless the curve relating effect to dose shows a reasonably steep rise". The method of Fujiwara et al. (1980) of injecting animals over a period of $48 \mathrm{~h}$ and performing the autopsy $96 \mathrm{~h}$ after the first injection could have contributed towards a lower response. It has been shown that the response of the ovary and uterus of the immature mouse to injected gonadotrophin decreased by 75 and $67 \%$ respectively when the animals were killed at $96 \mathrm{~h}$ instead of $72 \mathrm{~h}$ after the first injection (Levin \& Tyndale, 1937). Results obtained in the present investigation confirm the importance of the interval between doses and autopsy upon mouse uterine weight (Table 4). Another factor which may have contributed to the general lack of response in the bioassay of Fujiwara et al. (1980) was their use of a single constant dose of extract irrespective of the duration of pregnancy or placental weight. Four placental extracts produced significant increases in their bioassay but the response was greater than that of the hCG standard. Consequently, the potency of these extracts and the errors of the assays cannot be calculated nor can their validity be tested. Fujiwara et al. (1980) showed that the mean uterine weight of a group of YOK-ddy strain mice injected with $10 \mathrm{ng}$ oestradiol-17 $\beta$ was not significantly greater than that of the saline-injected controls. In the present investigation the mean uterine weight of mice injected with $5 \mathrm{ng}$ oestradiol- 
$17 \beta$ was significantly $(P<0.0002)$ greater than that of the saline controls and the mean uterine weight of mice injected with $10 \mathrm{ng}$ was equal to that produced by $0.25 \mathrm{i}$.u. hCG (Text-fig. 1). These results emphasize the difference in target organ sensitivity of the YOK-ddy and Schofield mice.

The negative results obtained by Hodgen et al. (1975) with extracts of rhesus monkey placentae after the 10th week of gestation are difficult to assess. Their bioassay, similar to the one used in the present investigation, was a modification of the Levin \& Tyndale (1937) method with a claimed sensitivity of $0 \cdot 1 \mathrm{i} . \mathrm{u}$. hCG. Their mice were younger, $16-18$ days, and therefore smaller, $6-9 \mathrm{~g}$. It might be that mice which are sensitive to small doses of the hCG standard preparation are not as responsive to relatively large amounts of crude placental homogenates. The absence of any information about the fiducial limits of estimates of potency, slope values, lambda values and linearity of response does not allow the validity or quantitative significance of their assays to be determined.

The hCG antiserum used in this study not only suppressed the bioactivity of the hCG standard and the macaque placental gonadotrophin but also the bioactivity of the urinary LH preparation (Table 5). Wide (1962) has reported that hCG antisera neutralized the gonadotrophic activity of human pituitary LH. Similarly, it has been shown that an antiserum to human pituitary LH inhibited the biological activity of hCG (Moudgal \& Li, 1961).

The present investigation shows that mouse uterine weight assays, done under optimum conditions, are sufficiently sensitive to measure the low concentrations of CG present in term placentae of monkeys. It must be concluded from past (Hobson, 1972a, b; Hobson \& Wide, 1972, 1981 ) and present investigations that CG is not restricted to macaque placentae of early pregnancy as has been claimed by Hodgen et al. (1975) and Fujiwara et al. (1980).

I am grateful to Professor T. G. Baker and Dr S. F. Lunn for the macaque placentae, to Dr. L. Wide for the anti-hCG serum, to Mrs J. Flockhart for technical assistance, and to Organon Teknika, England for financial assistance.

\section{References}

Brown, P.S., Cunningham, F.J. \& Finegan, R.P. (1959) Human urinary gonadotrophins. III. Comparison of assay methods. J. Endocr. 18, 191-196.

Burn, J.H., Finney, D.J. \& Goodwin, L.G. (1950) Biological Standardization. Oxford University Press, London.

Chai, C.K. (1960) Response of inbred and $F_{1}$ hybrid mice to hormone. Nature, Lond. 185, 514-518.

Diczfalusy, E. (1954) An improved method for the bioassay of chorionic gonadotrophin. Acta endocr., Copenh. 17, 58-73.

Fujiwara, T., Suzaki, Y., Yamada, Y. \& Honjo, S. (1980) Detection of macaque chorionic gonadotrophin in the placenta of the cynomolgus monkey (Macaca fascicularis). Japan J. Med. Sci. Biol. 33, 303-310.

Gaddum, J.H. (1931) The determination of vitamin A in cod-liver oils. Statistical examination of the results. Biochem. J. 25, 1113-1119.

Gaddum, J.H. (1953) Simplified mathematics for bioassays. J. Pharm. Pharmac. 5, 345-358.

Hobson, B.M. (1972a) Gonadotrophin concentrations in the placentae of man, the rhesus monkey and the marmoset. Folia primat. 18, 35-40.

Hobson, B.M. (1972b) New observations on the excretion of chorionic gonadotrophin during pregnancy in the rhesus monkey (Macaca mulatta). Folia primat. 18, $463-468$.

Hobson, B.M. \& Wide, L. (1972) A comparison between chorionic gonadotrophins extracted from human, rhesus monkey and marmoset placentae. J. Endocr. 55, 363-368.
Hobson, B.M. \& Wide, L. (1981) The similarity of chorionic gonadotrophin and its subunits in term placentae from man, apes, old and new world monkeys and a prosimian. Folia primat. 35, 51-64.

Hodgen, G.D., Neimann, W.H. \& Tullner, W.W. (1975) Duration of chorionic gonadotropin production by the placentae of the rhesus monkey. Endocrinology 96 , 789-791.

Hummel, K.P. (1942) Difference in response of mice of different strains to human pregnancy urine. Endocrinology 30, 74-76.

Katsman, P.A. \& Doisy, E.A. (1932) Preparation of extracts of the anterior pituitary like substance of urine of pregnancy. J. biol. Chem. 98, 739-754.

Levin, L. \& Tyndale, H.H. (1937) The quantitative assay of "follicle-stimulating" substances. Endocrinology 21, 619-628.

Moudgal, N.R. \& Li, C.H. (1961) An immunological study of a human pituitary interstitial cell-stimulating hormone. Nature, Lond. 191, 192-193.

WHO Expert Committee on Biological Standardization (1964) Wld Hlth Org. tech. Rep. Ser. No. 293, 12.

Wide, L. (1962) An immunological method for the assay of human chorionic gonadotrophin. Acta endocr., Copenh., Suppl. 70, 1-111.

Wide, L. (1969) Radioimmunoassays employing immunosorbents. Acta endocr., Copenh., Suppl. 142, 207221 . 